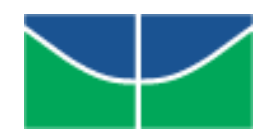

\author{
Universidade de Braślia \\ CET-Centro de Excelência em Turismo
}

Pós - graduação La to Sensu

Economia para o Turismo

\title{
A TAXA DE CÂMBIO E O TURISMO NO BRASIL
}

Paula Menezes dos Reis

Brasília-DF

Agosto de 2006 
Universida de de Brasilia

CET- Centro de Excelência em Turismo

Curso de Especialização em Economia para o Turismo

A TAXA DE CÂMBIO E O TURISMO NO BRASIL

Paula Menezes dos Reis

Maria de Lourdes Rollemberg Mollo

Doutora em Economia pela Université de Paris - Nanterre - França

Traba lho a presentado em cumprimento às exigências ac adêmic as parcia is do curso de pós-graduação lato sensu em Economia para o Turismo para obtenção do grau de Especia listas.

Brasilia - DF

Agosto de 2006 


\section{Resumo}

Esta monografia analisa a evolução do turismo no Brasil e a política cambial. Assim, no primeiro capítulo se faz uma descrição teónica sobre taxa de câmbio e regimes de câmbio altemativos. No segundo fala sobre a política cambial no Brasil desde 1990, mostrando em partic ular o que houve entre 94-99 (banda cambial) e depois de 1999 (câmbio flexível), destacando a apreciação do real no primeiro peńodo e as flutuações no segundo. No terceiro é analisados a evolução do turismo nacional nesse período, a entrada de turistas estrangeiros no Brasil, e o fluxo intemo, a movimentação de turistas brasileiros nos principais aeroportos. Por fim a conclusão a nalisa a relação sobre os efeitos do câmbio e o aumento ou diminuição da entrada de turistas, o aumento ou diminuição do turismo doméstico, descrevendo qual foi o impacto, efeitos.

Ipolítica cambial 2 turismo intemacional 3 turismo doméstico 


\begin{abstract}
This monograph analyzes the evolution of the tourism in Brazil and the connect with the exchange politics. The first chapter makes a theoretical description about tax e and altemative rate of exchange. In the second chapter, the text speaks on the exchange politics in Brazil since 1990, showing in particular what happened between 94-99 (exchange band) and after 1999 (flexible exchange), detaching the appreciation of the Real in the first period and the fluctuations after 1999. In the third one it is analyzed the evolution of the national tourism in this period, the entrance of foreign tourists in Brazil, and the intemal flow besides, the movement of Brazilian tourists at the main aimorts of the country. Finally the conclusion analyzes the connection betwen the effect of the exchange and the increase or the reduction of the intemational and domemestic tourism numbers, describing the impact and the effects of the exchange politics.
\end{abstract}

1 exchange politcs 2 intemational tourism 3 domestic tourism 


\section{SÚMARIO}

Introdução Pág 1

Capítulo 1

1. Os Diferentes Regimes Ca mbia is. Pág 6

1.1 Taxa Fixa Pág 6

1.2 Taxa Flexível. Pág 9

1.3 Banda Cambial. Pág 11

1.4 A Taxa de Câmbio e o Tunismo. Pág 12

Capítulo 2

2. A Evolução da Taxa de Câmbio Brasileira Pág 16

2.1 A História do Câmbio no Brasil.. Pág 16

2.2 Anos 1990 Pág 18

2.3 Anos 2000. Pág 28

2.4 Efeitos da Globalização Pág 33

Capítulo 3

3. A Relação Taxa de Câmbio e Turismo............................Pág 38

3.1 Entrada de Turistas Estrangeiros no Bra sil.....................Pág 39

3.2 Fluxo Intemo de Turista s.................................................

3.30 Impacto do Plano Real nas Agências de Turismo...Pág 46 Conclusão ..Pág 49

Bibliografia Pág 51 


\section{Introdução}

O objetivo dessa monografia é discutir a relação entre a política cambial e o turismo no caso do Brasil. Para isso, este primeiro capítulo descreve o que é a taxa cambial e seus regimes altemativos, câmbio fixo, câmbio flexível e banda cambial. Em seguida, faz a relação com o turismo, a nalisando como o câmbio interfere na demanda de turistas estrangeirose na demanda de turistas domésticos.

O capítulo dois analisa a evolução do câmbio no Brasil, e o terceiro capítulo analisa a evolução do turismo tanto doméstico quanto intemacional e sua relação com o câmbio.

No século XIX o regime monetário era o padrão-ouro, cuja presença foi dominante na "Era Dourada", entrando em colapso durante a Grande Depressão. Depois da Segunda Guerra Mundial, com o tratado de Bretton Woods, cada nação deveria definir o valor de sua moeda em relação ao dólar, que era conversível em ouro. Esse tratado, na verdade, é como ficou conhecida a Conferência Monetária e Financeira das Nações Unidas, com representantes de 44 países, para planejar a estabilização da economia intemacional e das moedas naciona is.

Os acordos assinados em Bretton Woods tiveram validade para o conjunto das nações capita listas lideradas pelos Estados Unidos, resultando na 
criação do Fundo Monetánio Intemacional (FMI) e do Banco Intemacional para Reconstrução e Desenvolvimento (BIRD).

Em Bretton Woods o sistema era de taxas fixas administradas. Aos poucos os países foram flexibilizando o câmbio.

Em 1971 foi suspensa a conversão do dólar em ouro, alterando a taxa de câmbio.

Desde então os países passaram a operar de forma diferente. Alguns operaram em um esquema de regime de câmbio flutuante, a Europa num sistema de taxas estáveis administradas de forma artic ulada entre os países a té a união monetánia e outros com o regime de câmbio fixo.

Os países em desenvolvimento, em particular na América Latina usaram nos anos mais recentes o câmbio fixo como forma de controle inflacionário, mas foram flexibilizando o câmbio a o longo do tempo. O sistema ma is comum hoje é o de câmbio flutuante.

As transações econômic as dentro de um país são simples. O comércio intemo funciona da seguinte maneira, quando queremos comprar uma fruta ou um peixe no Ceará, vamos realizar o pagamento em reais. Quando queremos, por exemplo, comprar um computador dos Estados Unidos, a transação é ma is complicada. O fabricante do computador necessita que o pagamento seja 
feito em dólar. Dessa forma surge uma ferramenta nova no mercado intemacional: a taxa de câmbio.

A taxa cambial representa "o preço" ao qual uma dada moeda corrente é trocada por uma outra. A taxa cambial representa o montante de moeda estrangeira que podemos obter por uma unidade de nossa própria moeda, por exemplo, o número de dólares que podemos comprar com um real. 1

Para compreender como são determinadas as taxas de câmbio, é necessário analisar o funcionamento do mercado cambial. O mercado cambial é o mercado em que as moedas dos diferentes países são transacionadas. É nele que se determinam astaxas de câmbio. ${ }^{2}$

Existem mercados que são especialistas nestas transações, mercados organizados em Tóquio, Nova lorque, Londres e Zurique, dentre outros. Mas cada país negocia e compra divisas, ou moeda intemacional, para suas transações intemacionais.

Quando a taxa de câmbio, medida pelo preço de moeda de um país em unidades monetánias de moeda intemacional, por exemplo, $R \$ 2,80 /$ US\$,

\footnotetext{
${ }^{1}$ Kennedy, Peter. Introdução à Macroeconomia. Pág 291.

2 Nord haus, William D. \& Samuelson, Paul A. Economia. Pág 820.
} 
diminui, dizemos que a moeda intema sofreu uma apreciação enquanto a moeda estrangeira uma depreciação. ${ }^{3}$

Existem diferentes regimes cambiais: taxa de câmbio fixa, taxa de câmbio flexível taxa administrada e banda cambial, que serão analisadas com mais detalhes a seguir.

Quando as taxas cambiais fixas são ajustadas, a moeda corrente que aprecia é valorizada e a moeda corrente depreciada é desvalorizada. ${ }^{4}$

A evolução do turismo no Brasil dependeu da evolução da taxa de câmbio, que influência o fluxo de entrada de turistas estrangeiros no Brasil, e o fluxo de saída de brasileiros para o exterior.

A taxa de câmbio influencia diretamente a entrada de turistas estrangeiros, pois quando o real sofre uma depreciação, um dólar compra ma is mercadorias em reais. Dessa forma, o turista estrangeiro tem ma is incentivo para conhecer o Brasil. Com o mesmo dólar que iria gastar, o turista estrangeiro passa a comprar um montante maior de mercadorias. A depreciação da moeda chama o tunista intemacional e aumenta o número de entradas de turistas e os gastos destes turistas ta mbém.

Um exemplo claro de como a taxa de câmbio influencia o turismo verifica-se na preferência recente pela Argentina. A crise da Argentina 
desva lorizou o peso e o país teve a sua demanda por turismo a umentada neste período. Durante o ano de 2002, viajar para a Argentina se tomou relativa mente muito barato.

A Argentina utilizava o sistema de câmbio ancorado, onde o Banco Central define o valor da moeda. Durante muitos anos a paridade do peso argentino estava equivalente a um dólar. Na crise o peso se desvalorizou, a traindo turistas do mundo inteiro. De forma a entender melhor a evolução do turismo no Brasil, veremos no capítulo 2 como evoluiu a taxa de câmbio brasileira nos anos 1990 e nos anos 2000. Em seguida, confronta remos com a evolução do turismo no Brasil. Antes, porém, é preciso entender os vários regimes cambia is, uma vez que o Brasil adotou vários deles a o longo do período analisado. É o que faremos a seguir. 


\section{Os Diferentes Regimes Cambiais}

\subsection{Taxas Fixas}

Como mencionado anteriomente, no peńodo do padrão-ouro a troca de uma moeda por outra qualquer tinha o seu valor fixo. O ouro era a moeda corrente mundial. As operações ocomiam em um regime de câmbio fixo (essas operações de regime de câmbio fixo são realizadas até hoje, porque há mercados que trabalham com este regime).

Num sistema cambial fixo, o banco central (ou seja, a autoridade monetária nacional) fixa o preço da moeda nacional em relação a uma moeda estrangeira. Esse preço fixo, às vezes, é chamado paridade da moeda. Entretanto, em certos casos, a paridade tem pouco significado econômico, porque, mesmo havendo um valor cambial oficial, não se consegue vender ou comprara moeda poresse valor. 5

A paridade monetária é a relação de valor entre moedas de países diferentes. Até a década de 70 utilizava-se o padrão ouro na conversão de valores de uma moeda para outra. Depois, começaram a ser utilizadas moedas fortes, como o dólar e a libra, como referência no cálculo da cotação de moedas, tanto no comércio intemacional como nas transferências de valores entre países.

\footnotetext{
${ }^{5}$ Sachs \& Larrain. Macroeconomia. Pág 321.
} 
Nas operações cambiais com taxa cambial fixa, o banco central troca moeda nacional por moeda estrangeira (ou vice-versa) para estabilizar a taxa de câmbio, ou para garantir que ela se mantenha no nível desejado. Aumenta ou reduz seu estoque de ativos estrangeiros trocando moeda nacional pela estrangeira para manter a taxa de câmbio constante. ${ }^{6}$ Por exemplo, se há muita demanda por dólar, o preço do dólar em moeda nacional pode subir, a não ser que o govemo ofereça dólares para atender a toda a demanda, garantindo assim, o preço desejado.

Existem três maneiras de deteminar a taxa de câmbio num sistema de câmbio fixo. A primeira é ancorando 70 valor da moeda nacional no valor da moeda de outra nação, e depois o govemo se dispõe a comprar e vender a moeda estrangeira à taxa escolhida. As nações envolvidas podem também fazer um acordo.

Na âncora unilateral, o valor da moeda nacional é fixado em relação à moeda de uma nação industrializada. Dessa maneira, a primeira nação é responsável pormanter a taxa cambial no valor combinado, comprometido.

No sistema de arranjo cambial cooperativo, a responsabilidade é compartilhada pelas nações envolvidas, a taxa de câmbio fixa é de comum acordo entre essas nações.

\footnotetext{
${ }^{6}$ Sachs \& Larrain. Macroeconomia. Pág 327.

7 Taxa cambial ancorada, indica que o preço da moeda é definido pelo banco central, mas pode ser alterado se as circunstâncias exigirem.
} 
Quando o govemo garante uma determinada relação entre o real e o dólar, ele interfere na oferta ou na demanda com o intuito e compensar os movimentos de mercado e garantir a taxa de câmbio 8 . Como ocorreu no Brasil durante deteminada época, o câmbio era de 1 real = 1dólar, ou a taxa de câmbio era igual a $R \$ 1,00 / U S \$$. Como no gráfico analisado abaixo, imaginemos que o govemo fixe a taxa de câmbio em $R \$ 2,4 /$ US\$ e haja um aumento de demanda de D1 para D2 elevando a taxa para $\mathrm{R} \$ 2,5 /$ US\$. Para evitar isso, o govemo tem que aumentar a oferta para 02, mantendo a taxa de câmbio desejada que é $R \$ 2,4 /$ US\$, ou reduzir sua demanda para que, somada à do mercado, que aumentou, a demanda total permaneça em D1.

Se a demanda por dólares aumenta, o govemo precisa ofertar dólares, ou diminuir sua própria demanda, mas se a oferta de dólaresaumenta para $\mathrm{O} 2$, o govemo precisa comprá-los à taxa deteminada, o que requer que aumente a demanda para D2. Para garantir a taxa fixada, é preciso que disponha de reservas para atender a qualquer demanda a essa taxa. ${ }^{9}$

Neste regime, a autoridade monetánia estará obrigada a comprar todo o excesso de moeda estrangeira que resultar, por exemplo, de um ingresso de capitais acima do déficit em conta comente, ou a vender a quantia equivalente ao excedente de demanda por divisas, no caso de uma saída de capita is (ou entrada inferior ao défic it nas transações correntes).

8 Mollo, Maria de Lourdes Rollemberg \& Amado, Adriana Moreira. Noções de Macroeconomia. Pág 126.

${ }_{9}^{9}$ Mollo, Maria de Lourdes Rollemberg \& Amado, Adriana Moreira. Noções de Macroeconomia. Pág 126. 


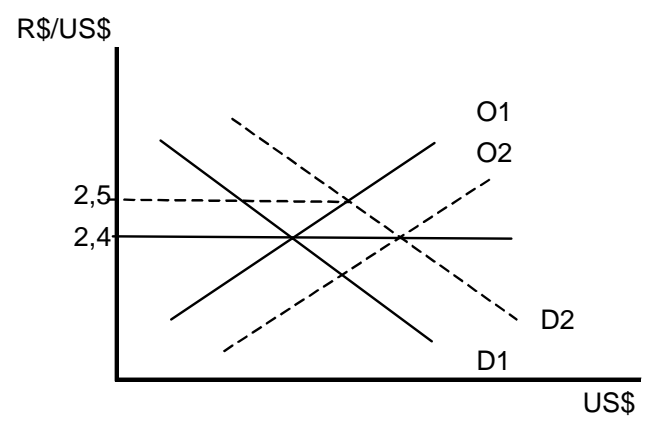

\subsection{Taxa Fexível}

Nas operações com regime de taxas flexíveis de câmbio ou taxa flutuante, os bancos centra is permitem que as taxas de câmbio se ajustem, a fim de igualar a oferta e a demanda da moeda estrangeira. 10

A taxa de câmbio de mercado ocorre quando a oferta e a procura de bens, serviços e fluxos de capita is estão em equilíbrio. ${ }^{11}$

As flutuações na demanda e na oferta de moeda estrangeira acomodam-se por meio da alteração de preço da moeda estrangeira em relação à nacional. O banco central define a oferta monetária sem se

10 Fisher, Stanley \& Dombusch, Rudiger. Macroec onomia. Pág 553.

${ }^{11}$ Nordha us, William D. \& Samuelson, Paul A. Ec onomia. Pág 821. 
comprometer com uma taxa cambial especifica e, depois, permite que ela flutue em resposta a os distúrbios ec onômic os. 12

Quando o banco central não interfere no mercado, nem comprando e nem vendendo moeda estrangeira, ocorre uma flutuação limpa.

Quando as nações, via autoridade monetária, fazem transações com taxas flexíveis e tentam influenciar o valor da sua moeda realizando transações no câmbio de moeda estrangeira, ocorre uma flutuação suja.

A característica do regime de taxa flexível é que a taxa de câmbio é determinada exclusivamente pelas forças de mercado. Um desequilíbrio no mercado de câmbio, motivado, por exemplo, por um deslocamento da demanda, é resolvido a través de uma mudança na taxa de câmbio.

Se as exportações aumentam, cresce a oferta de dólares, passando de O1 para 02 e seu valor cai, reduzindo a taxa de câmbio de r1 para r2. Isso significa diminuir o valor do dólar ou apreciar o real. Se as importações aumentam, a demanda por dólares cresce de D1 para D2, elevando o seu preço em reais. Dessa forma, eleva-se a taxa de câmbio de r1 para r3 e reduzse o valor do real em relação ao dólar, ou seja, o real é depreciado. ${ }^{13} \mathrm{~A}$ figura abaixo ilustra a explicação.

\footnotetext{
12 Sachs \& Larrain. Macroec onomia. Pág 328.

${ }^{13}$ Mollo, Maria de Lourdes Rollemberg \& Amado, Adriana Moreira. Noções de Macroeconomia. Pág126.
} 


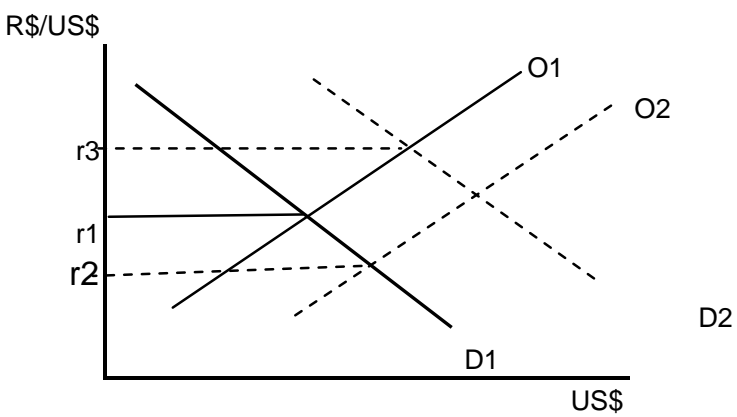

\subsection{Banda Cambial}

A Banda Cambial é a banda ou limite deteminado pelo Govemo para a flutuação do real frente ao dólar. ${ }^{14}$

É o sistema através do qual o Banco Central define periodicamente faixas para flutuação da taxa de câmbio, e intervém no mercado interbancário de câmbio sempre que a cotação da moeda ficar acima, ou abaixo dessa faixa, deixando o mercado agir no interior da banda. Esse sistema de controle foi usa do no Brasil durante o Plano Real. 15

A intervenção do Banco Central é feita de duas maneiras: através do uso de reservas do Banco Central e da deteminação da taxa de juros. A taxa de juros se ajusta a o nível necessá io para a manutenção das bandas cambiais, a tra indo ou a fugentando capita is extemos.

Vamos supor que a banda cambial seja fixada num limite inferior de $\mathrm{R} \$$ $2,00 /$ US $\$$ e o superior, de $R \$ 3,00 /$ US $\$$. Se existir uma ameaça, do valor em rea is

\footnotetext{
${ }_{14}$ www.unb.br/face/eco/inteco/dic iona riob.htm

${ }^{15}$ www.shopinvest.com.br/br/glossario
} 
do dólar cai abaixo do limite inferior, como por exemplo, no ponto B, o govemo precisa comprar dólares, para impedir que o valor do dólar em relação ao real caia. Se ocorrer de se aproximar do limite superior, como no ponto A, o govemo vende dólares, para baixar seu valor em relação ao real.

O govemo pode também aumentar as taxas de juros do país em relação às taxas de juros do exterior, estimulando os estrangeiros a a plic ar recursos no país, aumentando o saldo positivo da Conta de Capital do país. A entrada conseqüente de dólares reduz seu valor em rea is e a taxa de câmbio cai. Ao contrário, se a taxa de juros cai isso afugenta capital, reduz a quantidade de dólares e eleva o preço de dólares em reais, ou seja, a taxa de câmbio.

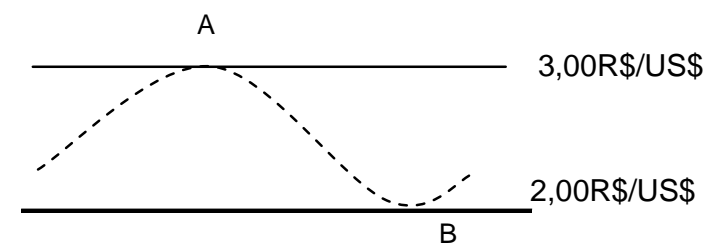

\subsection{A Taxa de Câmbio e o Turismo}

O impacto das variações cambiais tem muita relevância para o setor de turismo. A desvalonização de uma moeda de um país pode trazer resultados positivos ou negativos para o tunismo? Qua is os impactos da desvalonização do real perante o dólar para o turismo emissivo e para o turismo receptivo? O que oc orre com o turismo intemo? Aumenta ou diminui? E o turismo extemo? A entra da de turistas estrangeiros aumenta ou diminui?

Estas questões são de extrema relevância para o setor de turismo, que envolve relações econômicas, tanto intemaciona is como nacionais. Sendo assim, a variação da taxa de câmbio é crucial para o turismo de um país. 
Turismo emissivo é aquele onde o turista residente do próprio país se dirige a outros países. É a saída de residentes no Brasil para o exterior.

Em relação ao turismo emissivo, dois pontos podem ser destacados: a desvalorização da moeda nacional desestimula as viagens ao exterior. Já a valorização da moeda nacional estimula as viagens ao exterior.

Quando o valor do real cai em relação ao dólar, as viagens ao exterior se tomam mais caras e o resultado é que ocorre uma diminuição do turismo emissivo, ou seja, menos brasileiros estão viajando para o exterior. Os brasileiros optam, então, porviajar pelo país.

Quando o valor do real cresce em relação ao dólar, ocorre um aumento na demanda por viagens para o exterior, ou seja, se tem mais brasileiros indo para fora do Brasil. Com isso se tem um aumento do fluxo de turismo emissivo e, uma elevação das despesas extemas com turismo. A valorização do real, por outro lado desestimula o turismo intemo e tende a reduzir o numero de turistas domésticos.

Tunismo receptivo é aquele que os turistas não residentes procedem de um determinado país. Refere-se à entrada de turistas estrangeiros.

Quando o valor do real cai em relação ao dólar, viajarpara o Brasil tomase mais barato, ou seja, tem-se mais estrangeiros viajando para o Brasil, estimulando a promoção do turismo brasileiro. Assim, sempre que o real se 
desvaloniza em relação ao dólar, está a traindo mais turista estrangeiro. Para a demanda tuństica como um todo, a desvalonização do real é positiva. Além disso, como o turismo emissivo se toma caro, há mais incentivo ao aumento do turismo doméstico.

Quando o valor do real aumenta em relação ao dólar, viajarpara o Brasil toma-se mais caro, ou seja, ocorre um desestímulo à vinda de turistas estrangeiros. O turista estrangeiro vai substituir a viagem cara por um produto ma is barato, ma is compatível com o seu orça mento.

Dessa maneira pode-se concluir que moeda valorizada é boa para o turismo emissivo e moeda desvalorizada é boa para o turismo receptivo, aumentando os ganhos de câmbio vindos do exterior. Como a moeda desvalorizada estimula também o turismo domestico, observa-se que economicamente ele é melhor para o setor tuństico, que passa a crescer tanto pela criação de receitas intemas quanto pela absorção de divisas aumentando o PIB brasileiro.

Assim, as variações cambia is interferem diretamente no desempenho do turismo. As oscilações cambiais são então deteminantes no fluxo de turistas, interferindo no fluxo emissivo e receptivo de um país e no tunismo doméstico.

De forma a analisar o impacto das flutuações cambiais sobre o turismo vamos analisar no capítulo três a evolução do turismo doméstico e 
intemacional do país, a presentando sua relação com a evolução do câmbio, através de dados estatísticos. 


\section{A Evolução da Taxa de Câmbio Brasileira.}

\subsection{A Histónia do Câmbio no Brasil}

A história da política cambial no Brasil, tendo como base a chegada de Dom J oão VI, divide-se em três períodos. O primeiro está contextualizado pela fundação do primeiro Banco do Brasil em 1808, correspondendo à época onde as nações deviam manter paridade fixas com relação ao ouro. 16

As taxas de câmbio no Brasil estão agrupadas em dois segmentos, taxas administradas ou taxas livres, abrangendo todo o período, desde 1899 e, taxas flutuantes, que vigoraram no período de janeiro de 1989 a janeiro de 1999. 17

O peńodo abrangido pelas séries de taxas de câmbio englobou grande diversidade de políticas cambiais, apresentando em deteminadas épocas taxas fixadas (administradas) pelas Autoridades Monetárias, em outras, taxas livremente pactuadas pelos intervenientes do mercado (livres) e, ainda, perío dos em que vigoraram taxas administra das e taxas livres. ${ }^{18}$

Depois de 1929, à medida que avançava o processo de desintegração da economia intemacional, uma fase nova se inicia na política cambial do Brasil, cuja principal ca racterística eram os controles ca mbia is. De 1929 a té 1970 o Brasil utilizou diversos regimes: taxas oficia is fixas, monopólio cambial para o Banco do Brasil com câmbio negro, câmbios múltiplos, com quotas ou com

16 www.econ.puc-rio.br

17 Idem. 
leilões, registro para entrada, imposto sobre operações de câmbio, limites a certas operações, depósitos prévios, prazos mínimos ou máximos, indexação cambial, em fim uma série de políticas cambiais, datadas da seguinte maneira. 19

De fevereiro de 1953 a outubro de 1961foram uzadas taxas livres, utilizando-se as cotações divulgadas pela Carteira de Câmbio do Banco do Brasil. Entretanto, nesse peńodo, vigoraram também as taxas administradas, cujos valores, de venda foram fixados em: CR\$ 18,72, de fev/1953 a jul/1953; CR \$ 18,82, de ago/1953 a dez/1958 e, CR\$ 18,92, de jan/1959 a fev/1961. Numa primeira etapa, a maioria das transações cursou o sistema de taxas administradas. No decorrer do peńodo, observou-se tendência de ampliação das operações transaciona das no sistema de taxas livres.

De novembro de 1961 a fevereiro de 1990 foram observadas taxas administradas. ${ }^{20} \mathrm{~A}$ era dos controles cambia is começa a terminar quando a Europa vai retomando à conversibilidade e os Estados Unidos deixam oficialmente o padrão-ouro. O Brasil depois da crise da dívida extema nos anos de 1980 começa um processo de libera lização cambial. ${ }^{21}$

\footnotetext{
18 www.bacen.gov.br

${ }^{19}$ www.econ.puc-rio.br

20 www.bacen.gov.br
} 


\subsection{Anos 1990.}

No final do govemo Samey, durante o peŕodo de primeiro de janeiro a quatorze de março de 1990, houve continuidade na política de minidesvalorizações diárias da moeda, que vinha desde a Velha República. Nessa época a nossa moeda era o cruzado.

O sistema de minidesvalorizações não tinha regras explícitas, isto é, não especificava, formalmente, o intervalo e a referência para o processo. Esse modelo buscava uma taxa real fixa (contraditoriamente às aparências), visto que a desvalonização dada a cada dia visava repor o que a inflação havia "roubado" da taxa de câmbio. A política de minidesvalorizaçõesera chamada de crawling peg. Trata de um sistema que pemite mudanças escalonadas para atingir determinado objetivo. ${ }^{22}$ Como o objetivo era eliminar a inflação para garantir a competitividade da economia brasileira, á formula a dotada era desvalonizar o câmbio na proporção da diferença entre as taxas da inflação brasileira e as do resto do mundo.

O Banco Central fixava de véspera a taxa de compra - taxa com base na qual os bancos compravam no mercado primário - a taxa de venda - taxa com base na qual os bancos vendiam no mercado primário - a taxa de repasse - taxa pela qual o Banco Central comprava dos bancos-e, por fim, a taxa de cobertura - taxa pela qual o banco Central vendia aosbancos. ${ }^{23}$

\footnotetext{
${ }^{21}$ www.econ.puc-rio.br

22 Filho, Emilio Garofalo. Câmbios no Brasil. Pág 138.

23 Idem.
} 
Prosseguiam as intervenções, via mercado de ouro, compra e venda, e nos mercados de taxas flexíveis, dólar turismo e paralelo.

No govemo Collor em quinze de março de1990, ocorre a mudança de cruza do para cruzeiro novo. 24

A a doção da livre flutuação da moeda extinguiu a estrutura de compra / venda / repasse / cobertura. Ademais, o Banco Central só compraria segundo disponibilida des em c ruzeiro. 25

Em abril de 1990, a inda com Collore a mesma equipe, com o cruzeiro em escassez e a tendência de valonização da nova moeda, o Banco Central passa a operar, pontualmente, no mercado de câmbio, comprando e vendendo moedas.

Operações pontuais eram as compras e vendas realizadas fora dos leilões, sem anúncio prévio, porque nomalmente quando cobertos certos bancos têm grande oferta ou grande demanda de moeda, que pode vir a afetar fortemente a tendência do mercado. As operações pontuais visavam resolver problemas loc a lizados.

Com a sobrevalonização do cruzeiro, entrando em cena a edição do Plano Collor Il, houve congelamento de preçose de taxas de câmbio durante o

\footnotetext{
24 Idem.

${ }^{25}$ Filho, Emilio Garofalo. Câmbios no Brasil. Pág 138.
} 
mês de fevereiro de 1991, gerando nova sobrevalorização da moeda nacional e ocorreu a adoção do sistema de leilões de compra e venda de câmbio.

Ocorre uma maxidesvalorização do cruzeiro, devido à queda continua do nível de reservas intemacionais e à conseqüente necessidade de se revitalizarem as exportações, mantendo-se o modelo de desvalorização por leilões.

Logo depois, o Banco Central é autorizado a operar no mercado flutuante, gerando descontinuidade das operações com ouro para equilíbrio do próprio câmbio flutuante e do paralelo.

Em outubro de 1992 devido ao impeachment de Femando Collor, ocorre uma mudança de govemo em outubro assume Itamar Franco, e ocorre um festival de mudanças nos cargos de ministros da fazenda, presidente do Banco Central e diretores da área extema do Banco Central. 26

O Brasil adotou durante duas décadas e meia um regime de minidesva lorizações cambia is passivas, cujo objetivo era manter estável a taxa de câmbio real, de forma a presenvar a competitividade extema da economia, sendo através das desvalorizações periódic as que acompanhavam o ritmo da inflação. 27

\footnotetext{
${ }^{26}$ Filho, Emilio Garofalo. Câmbios no Brasil.. Págs 139, 140.

27 Studart, Rogério; Paula, Luiz Femando Rodrigues de; Sic sú, J oão; Souza, Francisco Eduardo Pires de \& Carvalho, Femando J . Cardim de. Economia Monetária e Financeira. Pág 424.
} 
Em primeiro de agosto de 1993, é criado o cruzeiro real. O Banco Central administrava a desvalorização da moeda com base em um indexador, de forma a acompanhara inflação.

Em vinte de fevereiro de 1994, adota-se como indexador único da economia, inclusive para o câmbio, a Unidade Real de Valor - URV -, que passa a ser a moeda da economia brasileira (1 URV era equivalente a 1 dólar/ taxa de venda). Os preços em lojas eram cotados em URV, e as mercadorias eram pagas em cruzeiros rea is, segundo a taxa de conversão do dia.

Ainda em 1994, mais precisamente em primeiro de julho o cruzeiro real é substituído pela moeda real. 1 real é igual a 1 URV, que equivale a uma quantidade variável (dia a dia) de cruzeiros reais. ${ }^{28}$

O Plano real foi implementado em três fases. Na primeira, foi criado um Fundo Social de Emergência (FSE) com o intuito de obter um ajuste fiscal provisório das contas públicas. O objetivo era mostrar que o govemo federal possuía capacidade para arcar com as despesas orçamentárias, sem precisar das receitas da inflação.

Na segunda fase foi introduzida a Unidade real de Valor (URV), fomada pela média dos três principais índices de preços, calculados por diferentes instituições: dois índices de preços do consumidor (IPC/FIPE e IPC/IBGE) e um índice de preço geral (IGP-M/FGV).

28 Filho, Emilio Garofalo. Câmbios no Brasil. Pág 140. 
Na terceira fase o cruzeiro real é extinto, a nova moeda é o Real. A taxa de conversão foi de 2750 cruzeiros rea is $=1$ URV $=1$ real $=1$ dólar. A paridade estabelecida entre real e dólar ficou conhecida como banda cambial assimétrica, pois se estipulava o limite máximo de $\mathrm{R} \$ 1 /$ US $\$ 1$ e o limite mínimo seria determinado pelasforças de mercado.

Com a introdução do real, houve a proibição de todo e qualquertipo de indexação da economia, em todos os setores da economia, incluindo o setor financeiro.

Em princípio, é adotada a chamada livre flutuação do real em termos de taxas de câmbio, junto com o programa de restrição monetária, forte imposição de depósitos compulsórios pelos bancos junto ao Banco Central e juros altos. Mas como ainda havia alguma inflação e a moeda nacional e a moeda nacional não estava sendo desvalorizada, isso desestimulava as exportações.

Tendo em vista a excessiva valorização do real, o Banco Central volta a operar no mercado, por meio de leilões, estabelecendo um sistema de bandas não-explícitaso real era vendido a $R \$ 0,86 /$ US\$ e comprado a $R \$ 0,83 /$ US\$.

Inic ia-se o primeiro govemo de Femando Henrique Cardos em primeiro de janeiro de 1995, com remontagem da equipe econômica, que mantém, em princípio, a mesma essência da política cambial. 
É feita a primeira tentativa pelo Banco Central de fixar bandas de flutuação, explícitas, com resulta do desastroso, uma vez que, a o combinar um novo sistema (o da explicitação) com operações a termo, utilizando linguagem e valores não entendidos pelo mercado, criou-se uma grande confusão e uma grande demanda pordólares.

Em decorrência deste fato, cria-se uma novidade no modelo, adotam "minibandas" dentro da banda larga previamente definida. Essa altemativa de operar no modelo conhecido como "intrabanda", permite ao Banco Central, por meio de compras e vendas em leilões, conduzir a desvalorização, até o limite superior na "bandona", situação em que esta deve modificar. ${ }^{29} \mathrm{Ao}$ longo do perído 1994-1998 a inflação foi controlada porque a valonização do real estimulava importações que concomiam com os produtos brasileiros pressionando seus preços para baixo.

A política de âncora cambial passou por muitas fases de ajuste no início do Plano Real. A partir de 1996 se concretizou um sistema de crawling peg ativo, pormeio do Banco Central que desvalorizava a taxa de câmbio nominal, independente da taxa de inflação. A desvinculação do ritmo de desvalorização em relação à inflação tinha o objetivo de romper com as instituições do passado inflacionário da economia brasileira, caracterizada pela indexação de preçose rendimentos, inclusive a taxa de câmbio. 30

\footnotetext{
${ }^{29}$ Filho, Emilio Garofalo. Câmbios no Brasil. Pá gs 140 e 141.

${ }^{30}$ Studart, Rogério; Paula, Luiz Femand o Rodrigues de; Sic sú, J oão; So uza, Francisco Edua rdo Pires de \& Carvalho, Femando J . Cardim de. Economia Monetária e Financeira. Pág 424.
} 
Em 1996, a taxa de inflação caiu abaixo do ritmo da desvalorização, a regra cambial passou a constituir em um mecanismo de promoção de uma desvalonização real, lenta e gradual da moeda brasileira. Dessa forma buscavase comigir a apreciação real da moeda ocomida na fase anterior da política da âncora cambial, quando a evolução da taxa de câmbio seguiu um nitmo mais lento que a inflação. A desvalorização acumulada no ano era relativamente pequena, se comparada com o peŕodo pré - Plano Real, e como se tratava de um regime em que o Banco Central fixava a taxa de câmbio, foi denominado de câmbio semifixo. ${ }^{31}$

Desde março de 1995 a política era de duas bandas, uma larga e outra estreita, não houve, até inic io de 1999, espaço para o mercado deteminar a taxa de câmbio, que continuava a ser fixada através da política de intervenção do Banco Central. A banda larga não tinha significado pratico e, mesmo a banda estreita não chegava a caracterizar o regime de banda de flutuação. Devido ao fato de que a banda era muito reduzida, inferior a $0,5 \%$, até 98 , quando passou a $1 \%$. 32

Apesar de temores no cenário mundial, como as crises de balanço de pagamentos de países da Ásia e, depois, da Rússia, chegamos a o final de 1998 com Femando Henrique Cardoso reeleito.

\footnotetext{
${ }^{31}$ Studart, Rogério; Paula, Luiz Femando Rodrigues de; Sic sú, J oão; Souza, Francisco Edua rdo Pires de \& Carvalho, Femand o J. Cardim de. Economia Monetária e Financeira. Pág 424. 32 Studart, Rogério; Paula, Luiz Femando Rodrigues de; Sic sú, J oão; Souza, Francisco Edua rdo Pires de \& Carvalho, Femando J . Cardim de. Economia Monetária e Financeira. Pág 424.
} 
O Banco Central vinha perdendo reservas, reforçando rumores de uma política cambial ou de patamar de taxas de câmbio para melhorar a balança comercial e suprir o país de dólares, uma vez que começava a se notar a escassez dos fluxos financ eiros de ing resso e engrossar os de saída.

Para a menizar as expectativas não só na mudança de fluxos financ eirose queda nas reservas, como também nos mercados futuros, que denotam a busca de proteção para os devedores em moeda estrangeira - além de especuladores -, o Banco Central vinha realizando venda de dólares no merc ado futuro, na BM\&F.

O govemo então se decidiu por alterar a política cambial. Realizou-se uma mudança nas bandascambia is onde estivesse implícita, na banda inferior, uma desvalorização maior da moeda nacional, adotando-se, a partir disso, novo modelo de variação periódica das bandas, segundo uma média móvel das cotações observadas, e desenhando-se, no intervalo das bandas definidas, uma linha diagonal - endógena -, que delinearia o ritmo de desvalorização da moeda.

O mercado novamente não entendeu, gerando demanda por dólares tão grande que a taxa, prevista para flutuar até 1,32 (rea is por dólar), chegou a 2,20. 33

\footnotetext{
${ }^{33}$ Filho, Emilio Garofalo. Câmbios no Brasil. Pá gs 142.
} 
O Banco Central retira-se das operações de mercado futuro e, passa por uma nova reestruturação.

Sob nova direção o Banco Central optou por um sistema de livre flutuação das taxas de câmbio, mudando o enfoque da política econômica como um todo para o inflation target.

No último trimestre de 1999, o Banco Central realizou leilões de câmbio, adotando, em seguida, uma política de interferência por meio de ações pontua is, capazes de amortecer eventua is concentrações de grandes volumes de oferta e demanda de moeda. Voltando ao sistema de dirty floating. 34

O regime cambial de minidesvalorizações ativas durou até meados de 1999, que após uma perda de reservas que vinha ocorrendo há meses, o Banco Central deixou o real flutuar. Desde então o Brasil opera num regime de câmbio flutuante. 35

Além das mudanças nas regras da taxa de câmbio, uma outra transformação do regime cambial brasileiro nos anos 90 foi a liberação do acesso ao mercado de câmbio. Até o final da década de 80 havia limitação à compra de moeda estrangeira para fins de pagamentos de mercadonas e serviç os no exterior, restrições ma iores para saídas de capita is. Um exemplo é o turista que fosse comprar dólares para realizar uma viagem ao exterior podia

\footnotetext{
${ }^{34}$ Filho, Emilio Garofalo. Câmbios no Brasil. Pá gs 142.
} 
comprar, legalmente no máximo US\$ 500 e se fosse para América do sul ou Central, o limite era de US\$100. 36

O sistema de restrições cambia is começou a ser relaxado no final da década de 1980, com a criação de um segmento do mercado de câmbio de taxas flutuantes, separado do oficial de taxas fixas, no qual os agentes econômicos passaram a poder comprar e vender moeda estrangeira para finalida des a ntes proibidas ou limita das. ${ }^{37}$

De inic io as principa is operações de compra e venda de dólar eram para viagens e, foi denominado de dólar turismo, utilizado até hoje. O mercado de câmbio brasileiro é dividido em dois segmentos. O segmento livre: onde são realizadas as compras e vendas de moeda estrangeira relativas ao comércio exterior e às principais transações financeiras. O segmento flutuante: onde ocorrem as operações de turismo, cartões de créditos, exportações de ouro e pedras preciosas, investimentos brasileiros no exterior, compra de imóveis, transferências unilaterais, a lém de transações financeiras que no passado eram realizadas através do mercado paralelo.

No regime atual de câmbio asoperações de compra e venda de moeda estrangeira são realizadas entre o público e as instituições financeiras

\footnotetext{
35 Studart, Rogério; Paula, Luiz Femando Rodrigues de; Sic sú, J oão; Souza, Francisco Edua rdo Pires de \& Carvalho, Femando J . Cardim de. Economia Monetária e Financeira. Pág 424. 36 Studart, Rogério; Paula, Luiz Femando Rodrigues de; Sic sú, J oão; Souza, Francisco Edua rdo Pires de \& Carvalho, Femando J. Cardim de. Economia Monetária e Financeira. Pág 425. ${ }^{37}$ Studart, Rogério; Paula, Luiz Femand o Rodrigues de; Sic sú, J oão; So uza, Franc isc o Eduardo Pires de \& Carvalho, Femando J . Cardim de. Economia Monetária e Financeira. Pág 426.
} 
autorizadas a operar no mercado de câmbio. ${ }^{38} \mathrm{Com}$ a livre flutuação do câmbio a moeda brasileira desvalorizou-se e as exportações começaram a crescer, superando as importações e valorizando os défic its do peńo do anterior.

\subsection{Anos 2000.}

Em 2000, completou-se o segundo ano de vigência de câmbio de livre flutuação. Nesse regime, as intervenções no mercado doméstico de câmbio pelo Banco Central se restringiam a evitar que a taxa de câmbio oscilasse em curtos espaços de tempo, ocorrendo a desvinculação do nível de reservas intema ciona is dos resulta dos do merca do cambial.

As intervenções do Banco Central eram conduzidas entre dealers, instituições credenciadas a operar no mercado de câmbio e de títulos da dívida pública, viam operações interbancárias de compra e venda de divisa, realizada diretamente ou por leilão eletrônico ou telefônica, com oferta simultânea a pelo menos cinco dealers.

As principais medidas visando adaptação do mercado de câmbio ao regime cambial de taxas flutuantes foram adotadas em 1999. Em 2000, foram editadas medidas objetivando a abertura de novas oportunidades de inversão de capital extemo nos mercados acionário e financeiro brasileiros e o incentivo

\footnotetext{
${ }^{38}$ Studart, Rogério; Paula, Luiz Femando Rodrigues de; Sic sú, J oão; Souza, Francisco Edua rdo
} 
a captação de empréstimos extemos por residentes. Simulta neamente, foram implementadas sistemátic as direcionadas a a companhamento e controle dos fluxose capita is pelo Banco Central. 39

O ano de 2001 foi caracterizado pelo surgimento de fontes de pressão sobre o nível de taxas de câmbio. Quanto ao cenário extemo, as pressões foram devido à situação política e econômica da Argentina e também às incertezas quanto à recuperação da economia norte-americana. O agravamento da crise Argentina e os reflexos do atentado terrorista em setembro, nos Estados Unidos, refletiram em depreciação da moeda nacional.

A partir do início do ano de 2001, a cotação do dólar norte-americano passou a descrever uma trajetória ascendente. Em 30 de março, a taxa de câmbio alcançava $R \$ 2,16$ por dólar, em quanto em dezembro de 2000 era e $\mathrm{R} \$ 1,95$.

As intervenções do Banco Central no mercado de câmbio tomaram-se ma is freqüentes, sem prejuízo para a continuidade do regime de livre flutuação.

As medidas editadas pelo Banco Central no Brasil em 2001 estiveram direcionadas à regulamentação dos fluxos de capita is estrangeiros, expressa na edição do regulamento o Registro Declaratório Eletrônico, e a consolidação 
das nomas referentes à imposição de penalidades por irregularidades assoc ia das a capita is estrangeiros. 40

Os choques ocomidos na economia mundial, especialmente após o atentado de 11 de setembro de 2001, mostraram a importância da adoção do regime de taxas de câmbio flutuantes como resposta a essas situações de instabilidade financeira. A crise intemacional e os efeitos inflacionários de uma depreciação da moeda brasileira exigiram que Banco Central atuasse de modo a aliviar parte da pressão sobre a taxa de câmbio por meio e emissão de títulos indexados a taxa de câmbio, bem como de intervenções no mercado à vista.

A estabilização que se observou a partir de novembro de 2001, com deslocamento do risco Brasil da crise Argentina, manteve-se, de certa maneira, até meados de abril de 2002. Com a apreciação do real, o Banco Central interrompeu a rolagem dos juros vincendos dos títulos indexados ao dólar.

A taxa de câmbio mostrou-se relativamente estável no primeiro quadrimestre de 2002. ${ }^{41}$

No ano de 2002, no Brasil a redução registrada no fluxo de créditos foi intensificada pelas incertezas associada à iminente transição do govemo, registrando-se expressiva depreciação de câmbio.

\footnotetext{
${ }^{40}$ Relatório Anual 2001 - Banco Central do Brasil.

${ }^{41}$ Relatório Anual 2002 - Banco Central do Brasil.
} 
A atuação do Banco Central foi pautada por medidas que inibissem a volatilidade da moeda norte-americana.

A percepção do mercado quanto ao compromisso do govemo eleito com os princípios básicos que garantiram a estabilidade monetánia e os resultados favoráveis registrados pela balança de comercial, refletindo a política comercial, ganhos intemos de produtividade, assim como a depreciação do real favoreceu, na passagem de 2002 para 2003, a melhora da expec tativa dos investidores intemaciona is.

Nesse cenário, a taxa de câmbio passou a apresentar tendência de va lorização.

Com a redução da volatilidade no mercado de câmbio, a apreciação do real e o controle da inflação, criaram-se às condições para o início da flexibilização das restrições ca mbia is impostasaos bancos em outubro de 2002.

Em julho de 2003, o Tesouro Nacional começou a atuar mais efetivamente no mercado de câmbio.

Contribuíram também para maior tranqüilidade no mercado de câmbio os termos do novo acordo firmado ao final de 2003 com o Fundo Monetário Intemacional. De acordo com as novas cláusulas, o pagamento foi substituído por um empréstimo e ademais, os vencimentos para 2005, 2006 e 2007 foram 
reescalonados, para diminuir em US\$ 6 bilhões, a concentração de pagamentos em 2005. 42

Em 2004, manteve-se a estratégia de redução da parcela da dívida pública intema atrelada ao dólar e de compra e divisas no mercado para pagamentos da dívida extema e para recomposição do nível de reservas intemacionais, com visitas a reduzir a vulnerabilidade do balanço de pagamentos do balanço patrimonial do setor público.

A partir de setembro de 2004, a moeda brasileira experimentou expressiva apreciação, encerrando o ano a $\mathrm{R} \$ 2,65$ pordólar.

O resultado global do mercado de câmbio em 2004 proporcionou o ingresso líquido de US\$ 6,4 bilhões de recursos contratados. Esse resultado constitui-se no mais relevante desde 1996. 43

Em 2005, a política cambial pautou-se pela manutenção de redução à exposição cambial do setor público, e de recomposição das reservas, seja pela aquisição de divisas pelo Banco Central no mercado à vista, seja pelas contratações o Tesouro Nacional para liquidação da dívida de sua responsabilidade.

42 Relatório Anual 2003 - Banco Central do Brasil.

43 Relatório Anual 2004 - Banco Central do Brasil. 
Em fevereiro de 2005, com o objetivo de acelerar a redução da exposição cambial do setor público, o Banco Central passou a realizar leilões de swap cambial. Com periodic idade semanal, nos qua is assume posição ativa em variação cambial e passiva em taxas de juros doméstica.

Em novembro do mesmo ano, o Banco Central anunciou mudanças nas regras dos leilões, estabelecendo que pudessem ser realizados a qualquer dia da semana.

No mercado cambial, a tendência de contínua apreciação da moeda brasileira ante o dólarnorte-americano se manteve desde meados de 2004. Em 11 de novembro de 2005, o dólar atingiu sua menor cotação no ano, $\mathrm{R} \$ 2,16 /$ US\$, correspondendo a menor cotação desde 12 de abril de 2001. ${ }^{44}$

\subsection{Efeitos da Globalização}

A globalização implica na intensificação, ou seja, no aumento da concorrência. O aumento da concorrência levou ao abaixamento dos preços no mundo todo e foi importante para dar base nos programas antiinflação em vários países, tendo destaque a América Latina.

\footnotetext{
${ }^{44}$ Relatório Anual 2005 - Banco Central do Brasil.
} 
Ao liberar as importações, a globalização permitiu que entrassem no país mercadorias ma is baratas para concorrer com as naciona is. Essas mercadorias ma is baratas fizeram com que os empresários brasileiros fossem pressionados a baixar os seus preços. 45

A globalização reprime o conflito distributivo e impede que ele se reflita na elevação dos preços. Sendo assim, neste contexto perderam os empresários brasileiros, pois as indústrias deixaram de vender uma vez que suas mercadorias foram substituídas por similares importados, ganhando desse modo os estrangeiros que conseguiram vender ma is no Brasil. 46

A redução dos preços ocorreu no mundo inteiro devido à globalização, o que explica a caracterização dos anos 1980-90 como um peńodo do, sobretudo deflacioná rio. 47

No Brasil somente na década de 1990 se inicia a liberação e contribuiu para estabilização dos preços por meio do Plano real.

Como dito anteriomente no inicio dos anos 90, as taxas de inflação eram muito altas, essas taxas eram difíceis de abaixar por causa das indexações. Para interromper este processo era preciso convencer as pessoas que a inflação acabaria. O que contribuiu nesse processo foi a Unidade Real de Valor (URV).

45 Mollo, Maria de Lourdes Rollemberg \& Amado, Adria na Moreira. Noções de Macroeconomia. Pág 129.

${ }^{46}$. Mollo, Maria de Lourdes Rollemberg \& Amado, Adriana Moreira. Noções de Macroeconomia. Pág 129 
Com essa medida os salários passaram a ser convertido em URV, se houvesse aumento da inflação na moeda antiga, os salários não seriam afetados, assim acalmando os trabalhadores. Os capitalistas sabendo o valor dos salánios podeniam assim calcular, planejar melhor sua margem de lucro. Os consumidores podiam perceber quando os preços estavam aumentando ou estavam elevados dema is. 48

A URV foi substituída pelo real, nossa moeda corrente, utilizada até os dias de hoje. O govemo para poder trocar rea is por dólares na devida proporção de $\mathrm{R} \$ 1,00$ por US $\$ 1,00$, era preciso ter uma boa reserva de dólares para atender a demanda. O govemo de fato tinha essa reserva, devido à entrada de capitais extemos nos anos 90 e as altas taxas de juros. As pessoas que possuíam dólares rec ebiam o equivalente em rea is para a plic ar no Brasil. 49

Antes do Plano Real, para manter a competitividade dos produtos brasileiros no exterior a moeda brasileira era desvalonizada em relação ao dólar. Na proporção em que a moeda era depreciada, os exportadores recebiam mais quantidade de moeda brasileira por dólar exportado. Com a fixação da banda cambial, o govemo impediu que a moeda brasileira continuasse a desvalorizar. A inflação foi controlada, mas continuava ocorrendo em taxas baixase, vinha acumulando-se. 50

Como o valor do dólar não mudava em relação ao real, para compensar a inflação os custos de nossas exportações aumentavam. Sendo assim o real

\footnotetext{
${ }^{47}$ Idem. Pág 130.

${ }^{48}$ Mollo, Maria de Lourdes Rollemberg \& Amado, Adriana Moreira. Noções de Macroeconomia. Pág 131.

${ }^{49}$ Mollo, Maria de Lourdes Rollemberg \& Amado, Adriana Moreira. Noções de Macroeconomia. Pág 132.
} 
comprava menos produto intemo do que extemos, devido à inflação extema ser menor do que a intema. Dessa forma o real foi se valorizando em relação ao dólar, estimulando as importações e conduzindo os nossos preços para baixo.

Resumindo, a liberalização da conta de capital e as altas taxas de juros atraíram capitais. Essa entrada de capitais valonizou o real e estimulou as importações.

Com a liberalização sem controle das restrições e regulamentações estata is, fic a mos vulneráveis a o que acontece fora do Brasil. Por exemplo, se os Estados Unidos resolve aumentar a sua taxa de juro para resolver u problema intemo, reduz-se o diferencial de taxa de juros que estimula a entrada e a permanência de capita is no Brasil.

Podem ocorrer duas coisas, capita is fogem do país ou não chegam ma is no mesmo volume, obrigando o govemo brasileiro a aumentar a taxa de juros doméstica.

A fuga de capita is impede o controle da taxa de câmbio, porque a saída de dólares reduz a oferta de dólares aumenta o preço do dólar e desvaloriza a moeda nacional. Com os dóla res sa indo, não tem resenvas para vender e evitar a desvalorização da moeda. Aumentando a desvalorização do dólar, em conseqüência, aumenta as dívidas de quem tem contas a pagar em dólares. Isso pode levaros problemas de falências de bancose empresas. ${ }^{51}$

50 Idem. Pág 133. 
Para tentar evitar esta situação a medida utilizada foi a de elevar ma is a taxa de juros doméstica. Essa medida foi se tomando insustentável para manter a banda cambial no Brasil, e foi modificada, como dito anteriomente, mudando o regime cambial.

A globalização levou à vulnerabilidade financeira do país, porque facilitou a fuga de capitais em momentos de incerteza. 52

\footnotetext{
${ }^{51}$ Mollo, Maria de Lourdes Rollemberg \& Amado, Adriana Moreira. Noções de Macroeconomia. Pág 136.

${ }^{52}$ Mollo, Maria de Lourdes Rollemberg \& Amado, Adriana Moreira. Noções de Macroeconomia. Pág 137.
} 


\section{A Relação Taxa de Câmbio e Turismo}

Este capítulo descreve a taxa de câmbio e sua relação com o turismo, ou seja, qual é o impacto que a taxa de câmbio tem sobre o turismo. Tanto a desvalorização quanto a valorização da moeda nacional, no caso analisado o real em relação ao dólar, têm conseqüências, impactos diretos no turismo intemacional e no turismo doméstico, conforme vimos no capítulo 1.

A taxa de câmbio tem influência tanto no turismo receptivo, que é a entrada de turistas estrangeiros no Brasil, como também influencia as viagens de turismo doméstico, que retrata as viagens de brasileiros dentro do Brasil e ainda o turismo emissivo, que trata das viagens de turistas brasileiros para fora do país.

Para realizar esta análise, este capítulo esta rá dividido em duas partes: a primeira analisa a entrada de turistas intemacionais e a segunda analisa o turismo doméstico, ou seja, o fluxo intemo de turistas brasileiros. Complementando se faz uma análise do impacto do Plano Real sobre as agências de turismo.

A base de análise utilizada para obter a informação sobre a movimentação de turistas foi o Anuário Estatístico, elaborado pela Embratur Instituto Brasileiro de Turismo. A taxa de câmbio foi retirada do site do IPEA Instituto de Pesquisa Econômica Aplicada. 


\subsection{Entrada de Turista Estrangeiros no Brasil}

Para demonstrar a relação existente entre a entrada de turistas estrangeiros no Brasil e a taxa de câmbio os dados analisados consideram de entrada de turistas no peńodo de 1990 a 2005.

O que se pretende demonstrar, através dos dados estatísticos é que quando o valor do real cai em relação ao dólar, viajar para o Brasil toma-se mais barato, ou seja, têm-se mais estrangeiros viajando para o Brasil, estimulando a promoção do turismo brasileiro. Assim, sempre que o real se desva loriza em relação a o dólar, o Brasil esta a tra ind o ma is turista s estra ng eiros.

\section{Tabela 1}

ENTRADA DE TURISTAS NO BRASIL - 1990/ 2005

\begin{tabular}{cccccc}
\hline ANOS & TURITAS & ANOS & TURISTAS & ANOS & TURISTAS \\
\hline 1990 & 1.091 .067 & 1997 & 2.849 .750 & 2004 & 4.793 .703 \\
1991 & 1.228 .178 & 1998 & 4.818 .084 & 2005 & 5.358 .170 \\
1992 & 1.692 .078 & 1999 & 5.107 .169 & & \\
1993 & 1.641 .138 & 2000 & 5.313 .463 & & \\
1994 & 1.853 .301 & 2001 & 4.772 .575 & & \\
1995 & 1.991 .416 & 2002 & 3.783 .400 & & \\
1996 & 2.665 .508 & 2003 & 4.090 .590 & & \\
\hline FONTE: DPF e EMBRATUR & & & &
\end{tabular}




\section{GRÁRCO 1}

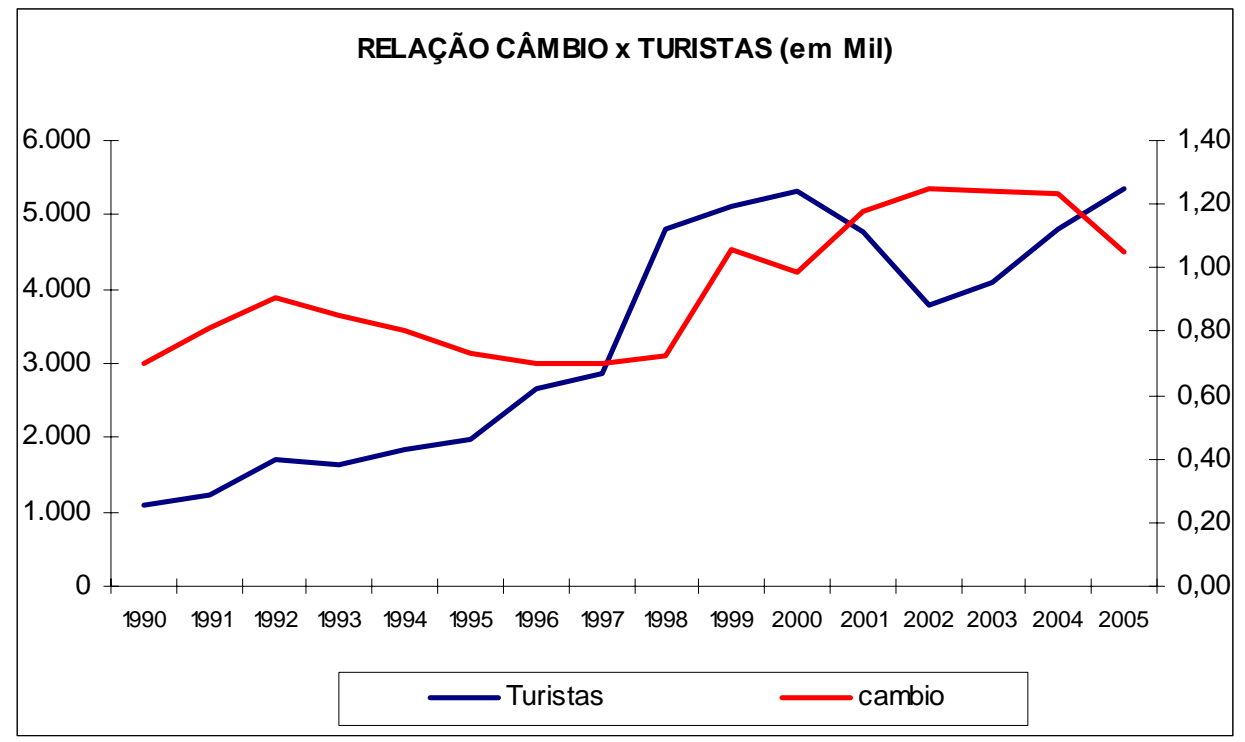

Fonte: IPEA e Anuário Estatístico-EMBRATUR

Analisando os dados de entrada de turistas no peńodo de 1990 até 1994, relacionados à taxa de câmbio, no primeiro momento que vai de 1990 a té 1992 observa-se que o câmbio está desvalorizando porque o dólar sobe de $\mathrm{R} \$$ 0,70/US\$ em 1990 para $R \$ 0,9 /$ US\$ em 1992, ou seja, é preciso mais reais para comprar um dólar, mostrando que o dólar valonizado estimula, a entrada de turista s estra ngeiros no Brasil.

De 1993 a té 1998, porém, o real se valoriza e mesmo assim o turismo cresce estimulado por outros fatores.

De 1999 em diante tem-se novamente uma desvalorização do câmbio, seguido de uma valonização do real perante o dólar. Nota-se que com a 
desvalorização do real o número de turistas teve uma alta expressiva, porém no peńodo 2001/2002, apesar da desvalorização o número de turistas reduz refletindo da crise vivida pela Argentina, que é o país de maior relevância no turismo nacional. Verifica-se essa informação na tabela 3.

O período de 2003 a 2005, mesmo com o real valorizado, o número de turistas tem um crescimento signific ante, o que pode estar relacionado com as ações de marketing intemacional que a Embratur - Instituto Brasileiro de Turismo vem desenvolvendo, divulgando o Brasil como destino tuństico no exterior, e com aumento do orçamento para o turismo viabilizando seu estimulo.

A tabela 2 demonstra o número de entradas de tunistas estrangeiros por região de residência.

\section{TABELA 2}

ENTRADA DE TURISTAS NO BRASIL, SEGUNDO REGIÕES DE RESIDÊNCIA PERMANENTE

\begin{tabular}{|c|c|c|c|c|c|c|c|c|c|}
\hline Regiões & 1990 & 1991 & 1992 & 1993 & 1994 & 1995 & 1996 & 1997 & 1998 \\
\hline África & 27.956 & 21.803 & 24.024 & 22.752 & 25.229 & 18.933 & 23.187 & 23.747 & 40.959 \\
\hline América Central & 8.044 & 6.810 & 7.926 & 6.838 & 10.281 & 13.482 & 18.571 & 19.047 & 31.503 \\
\hline América do Norte & 146.592 & 144.246 & 161.104 & 132.112 & 188.141 & 254.566 & 406.265 & 459.553 & 607.852 \\
\hline América do Sul & 527.744 & 700.339 & 1.100 .722 & 1.128 .409 & 1.158 .830 & 1.106 .063 & 1.405 .583 & 1.520 .367 & 2.810 .101 \\
\hline Ásia & 37.185 & 27.352 & 32.730 & 26.148 & 42.862 & 58.879 & 98.771 & 83.906 & 95.590 \\
\hline Europa & 326.478 & 314.331 & 349.971 & 311.863 & 407.972 & 509.153 & 671.152 & 701.684 & 1.144 .599 \\
\hline Oceania & 6.368 & 5.547 & 5.679 & 4.146 & 5.587 & 7.966 & 10.867 & 11.322 & 26.102 \\
\hline Oriente Médio & 7.644 & 5.932 & 7.288 & 6.145 & 8.501 & 12.168 & 17.532 & 19.049 & 29.735 \\
\hline Não Especificado & 3.056 & 1.809 & 2.639 & 2.725 & 5.898 & 10.206 & 13.508 & 11.075 & 31.642 \\
\hline TOTAL & 1.091 .067 & 1.228 .178 & 1.692 .078 & 1.641 .138 & 1.853 .301 & 1.991 .416 & 2.665 .508 & 2.849 .750 & 4.818 .084 \\
\hline
\end{tabular}


ENTRADA DE TURISTAS NO BRASIL, SEGUNDO REGIÕES DE RESIDÊNCIA PERMANENTE

\begin{tabular}{lccccccc}
\hline \multicolumn{1}{c}{ Regiões } & $\mathbf{1 9 9 9}$ & $\mathbf{2 0 0 0}$ & $\mathbf{2 0 0 1}$ & $\mathbf{2 0 0 2}$ & $\mathbf{2 0 0 3}$ & $\mathbf{2 0 0 4}$ & $\mathbf{2 0 0 5}$ \\
\hline África & 41.297 & 34.503 & 36.352 & 30.602 & 32.490 & 64.678 & 75.676 \\
América Central & 33.739 & 22.630 & 20.929 & 21.249 & 21.754 & 35.830 & 40.081 \\
América do Norte & 647.809 & 744.270 & 693.238 & 752.966 & 790.652 & 838.595 & 941.777 \\
América do Sul & 2.961 .694 & 3.036 .169 & 2.417 .526 & 1.459 .268 & 1.532 .234 & 1.829 .017 & 2.016 .202 \\
Ásia & 104.701 & 99.847 & 103.908 & 80.943 & 83.785 & 132.633 & 151.358 \\
Europa & 1.227 .835 & 1.305 .674 & 1.430 .724 & 1.375 .391 & 1.567 .708 & 1.834 .164 & 2.069 .221 \\
Oceania & 25.369 & 21.944 & 23.486 & 26.329 & 27.146 & 22.972 & 26.023 \\
Oriente Médio & 33.567 & 25.825 & 26.178 & 27.911 & 29.362 & 32.159 & 35.138 \\
Não Especificado & 31.158 & 22.601 & 20.234 & 8.741 & 5.459 & 3.655 & 2.694 \\
\hline TOTAL & $\mathbf{5 . 1 0 7 . 1 6 9}$ & $\mathbf{5 . 3 1 3 . 4 6 3}$ & $\mathbf{4 . 7 7 2 . 5 7 5}$ & $\mathbf{3 . 7 8 3 . 4 0 0}$ & $\mathbf{4 . 0 9 0 . 5 9 0}$ & $\mathbf{4 . 7 9 3 . 7 0 3}$ & $\mathbf{5 . 3 5 8 . 1 7 0}$ \\
\hline Fonte: DPF e EMBRATUR & & & & & & \\
\hline
\end{tabular}

Atra vés desta tabela verifica-se que de todas regiões, a América do Sul e a Europa, têm as maiores representa ções na entrada de turista s estrangeiros.

A tabela 3 mostra com mais precisão como é a entrada de turistas no Brasil porpaíses de procedência.

\section{TABELA 3}

ENTRADA DE TURISTAS NO BRASIL, SEGUNDO PAÍS DE RESIDÊNCIA PERMANENTE

\begin{tabular}{|c|c|c|c|c|c|c|c|c|c|}
\hline PAÍs & 1990 & 1991 & 1992 & 1993 & 1994 & 1995 & 1996 & 1997 & 1998 \\
\hline Áfricado Sul & 9.071 & 8.171 & 8.551 & 11.391 & 15.704 & 9.167 & 10.481 & 8.661 & 11.604 \\
\hline Costa Rica & 1.166 & 1.213 & 1.391 & 963 & 1.611 & 2.563 & 3.802 & 3.194 & 6.360 \\
\hline Estados Unidos & 120.314 & 112.423 & 117.802 & 91.471 & 164.209 & 224.577 & 356.000 & 402.200 & 524.093 \\
\hline Argentina & 253.506 & 405.512 & 598.346 & 794.766 & 787.117 & 657.942 & 858.189 & 938.973 & 1.467 .922 \\
\hline Paraguai & 55.127 & 68.961 & 71.876 & 77.967 & 93.728 & 90.716 & 118.563 & 146.581 & 451.693 \\
\hline Uruguai & 99.635 & 112.044 & 153.666 & 150.087 & 157.327 & 200.423 & 209.333 & 206.468 & 359.186 \\
\hline Japão & 20.564 & 16.057 & 17.862 & 13.082 & 21.667 & 30.219 & 48.474 & 39.194 & 38.143 \\
\hline Alemanha & 62.301 & 55.690 & 63.769 & 54.993 & 81.622 & 102.106 & 141.562 & 140.578 & 262.740 \\
\hline Espanha & 42.906 & 38.540 & 42.774 & 35.120 & 47.906 & 59.502 & 65.140 & 63.809 & 91.968 \\
\hline França & 39.108 & 35.222 & 37.443 & 32.786 & 41.792 & 55.257 & 75.277 & 84.552 & 121.272 \\
\hline Inglaterra & 25.416 & 24.009 & 24.691 & 18.975 & 29.949 & 38.520 & 58.201 & 62.308 & 117.518 \\
\hline Itália & 58.544 & 58.542 & 69.035 & 58.636 & 71.869 & 84.001 & 109.834 & 123.114 & 169.566 \\
\hline Portugual & 20.637 & 25.627 & 30.015 & 30.352 & 43.653 & 52.183 & 62.642 & 63.315 & 105.593 \\
\hline Austrália & 5.091 & 4.001 & 4.313 & 3.170 & 4.506 & 6.330 & 8.593 & 9.199 & 19.802 \\
\hline Outros & 277.681 & 262.166 & 450.544 & 267.379 & 290.641 & 377.910 & 539.417 & 557.604 & 1.070 .624 \\
\hline TOTAL & 1.091 .067 & 1.228 .178 & 1.692 .078 & 1.641 .138 & 1.853 .301 & 1.991 .416 & 2.665 .508 & 2.849 .750 & 4.818 .084 \\
\hline
\end{tabular}


ENTRADA DE TURISTAS NO BRASIL, SEGUNDO PAÍS DE RESIDÊNCIA PERMANENTE

\begin{tabular}{lcccccccc}
\hline \multicolumn{1}{c}{ PAÍs } & $\mathbf{1 9 9 9}$ & $\mathbf{2 0 0 0}$ & $\mathbf{2 0 0 1}$ & $\mathbf{2 0 0 2}$ & $\mathbf{2 0 0 3}$ & $\mathbf{2 0 0 4}$ & $\mathbf{2 0 0 5}$ \\
\hline Áfricado Sul & 12.577 & 13.917 & 15.365 & 20.798 & 26.963 & 32.415 & 36.139 \\
Costa Rica & 6.593 & 5.356 & 5.163 & 3.495 & 4.800 & 6.741 & 7.202 \\
Estados Unidos & 559.367 & 648.026 & 596.844 & 628.412 & 668.668 & 705.997 & 793.559 \\
Argentina & 1.548 .571 & 1.744 .004 & 1.374 .461 & 698.465 & 786.568 & 922.484 & 992.299 \\
Paraguai & 501.425 & 371.873 & 285.724 & 226.011 & 198.170 & 204.758 & 249.030 \\
Uruguai & 383.741 & 403.896 & 304.682 & 195.384 & 270.251 & 309.732 & 341.647 \\
Japão & 41.814 & 40.905 & 43.397 & 42.829 & 51.387 & 60.806 & 68.066 \\
Alemanha & 282.846 & 290.335 & 320.050 & 268.903 & 283.615 & 294.989 & 308.598 \\
Espanha & 99.677 & 110.765 & 126.928 & 114.050 & 122.641 & 155.421 & 172.979 \\
França & 131.978 & 165.117 & 184.759 & 199.613 & 211.347 & 224.160 & 252.099 \\
Inglaterra & 125.607 & 127.903 & 143.626 & 137.049 & 138.281 & 150.336 & 169.514 \\
Itália & 177.589 & 202.903 & 216.038 & 197.641 & 221.190 & 276.563 & 303.878 \\
Portugual & 115.088 & 147.143 & 165.898 & 203.126 & 229.594 & 336.988 & 357.640 \\
Austrália & 19.734 & 18.388 & 19.860 & 19.959 & 17.798 & 18.454 & 20.949 \\
Outros & 1.100 .562 & 1.022 .932 & 969.780 & 827.665 & 859.317 & 1.093 .859 & 1.284 .571 \\
\hline TOTAL & $\mathbf{5 . 1 0 7 . 1 6 9}$ & $\mathbf{5 . 3 1 3 . 4 6 3}$ & $\mathbf{4 . 7 7 2 . 5 7 5}$ & $\mathbf{3 . 7 8 3 . 4 0 0}$ & $\mathbf{4 . 0 9 0 . 5 9 0}$ & $\mathbf{4 . 7 9 3 . 7 0 3}$ & $\mathbf{5 . 3 5 8 . 1 7 0}$ \\
\hline Fonte: DPF e EMBRATUR & & & & & & & \\
& & & & & & & \\
\end{tabular}

Verifica-se, como citado anteriormente, a questão da Argentina que desde 1990 até 2001 apresentou o maior número de turistas, porém a partir de 2002 observa-se que esse número cai. Contudo a Argentina continua estando em primeiro lugar como país ma is importante para o turismo Brasileiro. Pode-se dizer que essa queda tem uma relação direta com a crise econômica. Além da Argentina, destacam-se nos últimos anos alguns países em importância qua nto ao número de turistas enviados ao Brasil: Estados Unidos, alguns países do Mercosul, Alemanha, Itália e Portugal. 


\subsection{Fuxo Intemo de Turistas.}

Para a na lisar o turismo doméstico, utilizo u-se o fluxo intemo dos aeroportos no Brasil que indica o número total de tráfego aéreo de passageiros nos princ ipa is a eroportos do país.

A tabela 4 demonstra a relação entre a evolução da taxa de câmbio e movimento doméstico de turistas entre os anos de 1990 a 2005.

\section{FLUXO INTERNO}

MOVIMENTO DE TURISTAS NO BRASIL - 1990/ 2005

\begin{tabular}{cccccc}
\hline ANOS & TURITAS & ANOS & TURISTAS & ANOS & TURISTAS \\
\hline 1990 & 13.422 .499 & 1997 & 14.849 .558 & 2004 & 36.544 .525 \\
1991 & 13.753 .171 & 1998 & 18.243 .571 & 2005 & 43.095 .828 \\
1992 & 11.128 .766 & 1999 & 20.781 .210 & & \\
1993 & 10.499 .893 & 2000 & 20.934 .622 & & \\
1994 & 11.197 .005 & 2001 & 25.097 .385 & & \\
1995 & 12.136 .481 & 2002 & 25.952 .516 & & \\
1996 & 12.742 .600 & 2003 & 25.452 .887 & & \\
\hline FONTE: INFRAERO & & & & & \\
TABELA 4 & & & &
\end{tabular}


GRÁFICO 2

REL AÇÃO CÂMBIO x TURISTAS (em mil)

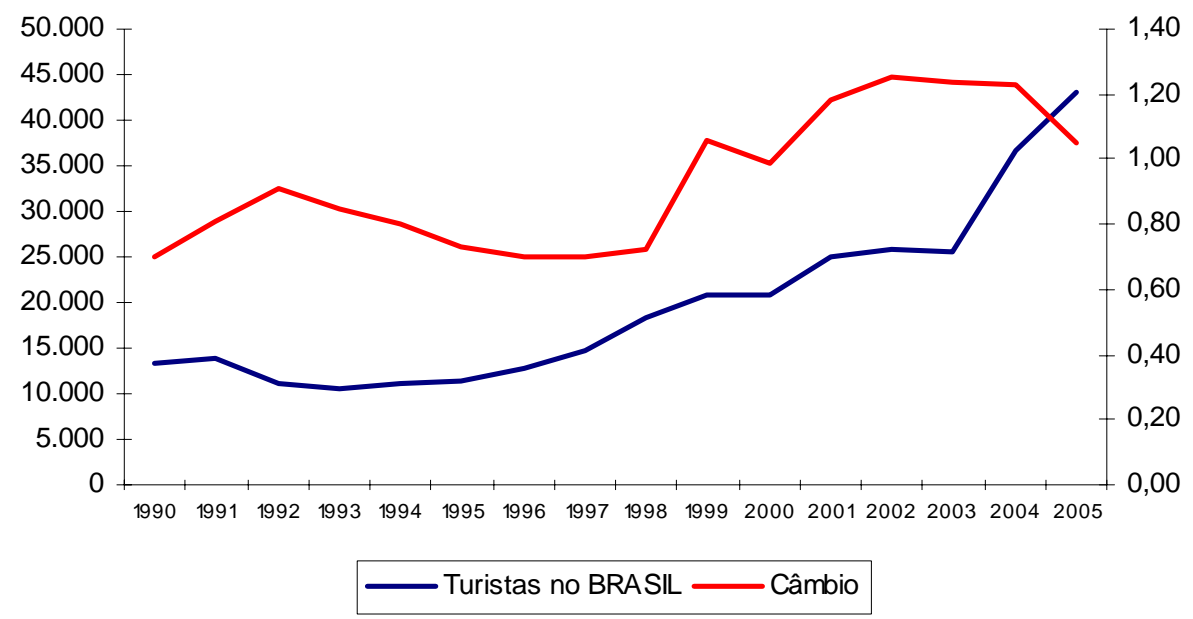

Fonte: IPEA e Anuário Estatístic o - EMBRATUR

O fluxo intemo nos aeroportos do Brasil demonstra que o turismo doméstico vem ao longo do período crescendo o que por sua vez, está associado a vánios fatores sociais e econômicos e não somente a taxa de câmbio. Vemos também que a sensibilidade do turismo doméstico à taxa de câmbio é maiorque o turismo intemacional.

Nos períodos em que o real está se valorizando, porém, como é o caso de 1992 a 1998 percebe-se que o número de turistas viajando intemamente tem ligeiro aumento, o que pode estar ligado ao fato de que houve um aumento do poder aquisitivo pós-plano real (1994). Outro fator é que a preferência das pessoas em viajar intemamente, optando por conhecer o país onde moram estimula dospor campanhas de incentivo do turismo doméstico. 
Comparando a curva de fluxo intemo de turistas com a curva de câmbio, pode-se dizer que a desvalorização do real entre 1999 e 2002 tem alta correlação com o número de viagens intemas. A idéia é de que, como o real está se desvalorizando em relação ao dólar, são necessánios mais reais para comprar/ trocar um dólar, dessa forma viajar para o exterior toma-se ma is caro, aumentando a demanda pelo turismo intemo.

Outro fator importante que ocorre no turismo doméstico é que quando o real está valonizado mais brasileiros estão indo para o exterior. Em 1994 o número de brasileiros indo para o exterior foi de 2.100 .000 em 1995 ocorre um aumento passando para 2.683.000. No período de 2002 a 2005 no qual o real tem ligeira valorização o número passa de 2.363 .942 para 4.704.449. Estes dados são uma estimativa, com base na saída de turistas e pesquisa sobre o turismo emissivo e receptivo intemacional, retirado do Anuário Estatístico da OMT Organização Mundial do Turismo.

\subsection{O Impac to do Plano Real nas Agências de Turismo.}

As fortes transformações trazidas pelo Plano Real para a economia brasileira também impactaram o segmento de agências de viagens. $O$ setorfoi afetado pela redução da inflação e, conseqüentemente, eliminação da receita inflacionária, pela apreciação da taxa cambial, que vigorou no primeiro ano do Real e pela substancial mudança de preços relativos. A evolução do preço das passagens aéreas e o aumento do preço dos serviços reforça ram os impactos sofridos pelo setor no período pós-real.53

\footnotetext{
${ }^{53}$ Milone, Paulo Cesar \& Lage, Beatriz Helena Gelas. Turismo Teoria e Prática. Pág 135.
} 
O impacto do Plano Real será abordado sob dois aspectos: impacto sobre a receita e o impacto na estrutura da demanda.

No peńodo anterior ao Real, uma das características de várias empresas era a geração de receitas inflacionárias, dado o elevado ritmo de crescimento dos preços. Nas agências ocomia o mesmo, uma vez que havia prazos mais longos para pagamento das empresas fomecedoras, principalmente empresas aéreas, do que elas recebiam dos clientes. Além de permitir uma certa flexibilidade na política de descontos, a receita inflacionária do setor era signific a tiva. ${ }^{54}$

A arbitragem na compra e venda de moedas estrangeiras criava espaço para gerar receitas, independemente da atividade específica. Dessa forma, o primeiro impacto do real foi a queda da receita inflacionária, que tirou das agências esse tipo de ganho. 55

Um segundo componente que prejudicou a receita das agências foi a taxa de câmbio, uma vez que a maior parte da receita vinha da venda de passagens intemacionais pagas em dólar que se desvalorizou depois do Plano Real. A estratégia de estabilização do Plano Real ao se apoiar fimemente na apreciação cambial reduziu a receita real das agências de viagens. ${ }^{56}$

\footnotetext{
54 Milone, Paulo Cesar \& Lage, Beatriz Helena Gelas. Turismo Teoria e Prática. Pág 135 55 Milone, Paulo Cesar \& Lage, Beatriz Helena Gelas. Turismo Teoria e Prática. Pág 135 56 Milone, Paulo Cesar \& Lage, Beatriz Helena Gelas. Turismo Teoria e Prática. Pág 135
} 
Outro elemento que contribuiu para reduzir a receita do setor foi a evolução do preço das passagens. Os preços rea is das passagens aéreas, tanto naciona is como intemaciona is sofreram queda a partir de $1994 .{ }^{57}$

A estrutura da demanda do turismo também se alterou com o Plano Real. Isso ocorreu por dois motivos: mudanças nos preços relativos e alteração no perfil de renda dos consumidores. As classes de menor poder aquisitivo experimentaram ganhos de renda com eliminação do imposto inflacionánio, o que pode explicar em parte o crescimento do turismo doméstico apesar da a preciação do real (gráfico 2). A disponibilidade de renda para viagense lazer, porparte da classe média alta, porém, passou a ser erodida a partir de meados de 1995.

A mudança de preços relativos foi outro ponto que tem que ser destacado. Com a implementação do plano de estabilização, o Real foi valorizado em relação ao dólar e outras moedas, barateando as viagens intemacionais, relativamente às nacionais, estimulando o turismo emissivo e desestimulando o receptivo. 58

57 Milone, Paulo Cesar \& Lage, Beatriz Helena Gelas. Turismo Teoria e Prática. Pág 136.

58 Milone, Paulo Cesar \& Lage, Beatriz Helena Gelas. Turismo Teoria e Prática. Pág 137. 


\section{CONCLUSÃO}

Esta monografia teve como objetivo demonstrar ra relação existente entre a política cambial e o turismo, descrevendo como o câmbio pode interferir na demanda de turistas estrangeiros e na demanda de turistas domésticos.

No primeiro capítulo foi realizada uma descrição do que é a taxa de câmbio e seus regimes altemativos. Em seguida, foi feita a relação com o turismo, demonstrando como o câmbio pode se relacionar com o turismo.

No segundo, foi feita uma descrição teórica da evolução do câmbio no Bra sil nos a nos 1990 e 2000.

De forma a analisar o impacto que as flutuações cambia is têm sobre o turismo, no terceiro capítulo foi demonstrada a evolução do turismo doméstico e do turismo intemacional, através de dados estatísticos.

Foi possivel constatar que existe de fato uma relação entre a taxa de câmbio e o turismo. Tanto a desvalorização como a valorização do real podem trazer impactos positivos ou negativos para o turismo, embora não sejam os únic os determinantes dele.

Quando a moeda nacional está valorizada, esta estimula a saída de brasileiros a o exterior. Já a moeda desvalorizada desestimula as viagens para fora do país, estimulando a entrada de turistas estrangeiros. 
Pode-se concluir que a moeda valorizada é boa para o turismo emissivo e a moeda desvalorizada é boa para o turismo receptivo, aumentando os ganhos de câmbio vindos do exterior. Com a desvalorização da moeda, o turismo doméstico também ganha, pois se tem mais brasileiros viajando intemamente. Assim, observa-se que economicamente a desvalorização da moeda é melhor para o turismo. O que passa a acontecer é que a economia cresce tanto pela criação de receitas intemasquanto pela absorção de divisas, aumentando o PIB - Produto Intemo Brasileiro.

Observa-se que as varia ções cambia is rea lmente interferem diretamente no desempenho do turismo. Essas variações são importantes como determinantes no fluxo de turistas, interfenindo no fluxo emissivo e receptivo, e também no turismo doméstico de um deteminado país. 


\section{Bibliografia}

Anuário Estatístico da EMBRATUR. Brasília. Ministério do Turismo \& Instituto Bra sileiro de Turismo - 1990 à 2004.

FILHO, Emilio Garofalo. Câmbios no Brasil. São Paulo, Editora: Cultura Editores Associadose Bolsa de Mercadorias \& Futuros - 2000.

FISCHER, Stanley \& DORNBUSCH, Rudiger. Macroeconomia. Tradução Maria Heloisa Souza Reis. São Paulo, 2 Edição. Editora: Mc Graw - Hill. - 1982.

JENKINS, Carson L. \& LICKORISH, Leomad J . Introdução ao Turismo. Tradução: Fabíola de Carvalho S. Vasconcelos. Rio de Janeiro, Editora: Campus - 2000.

KENNEDY, Peter. Introdução à Macroeconomia. São Paulo. Editora: Sa raiva 1982.

LAGR, Beatriz Helena Gelas \& MILONE, Paulo Cesar. Economia do Turismo. São Paulo, 7ạ Edição Revista e Ampliada. Editora: Atlas S\& A -2001.

LARRAIN, Felipe B. \& SACHS, Jeffrey D. Macroeconomia. Tradução: Sara R. Gedanke; Revisão técnica Roberto Luís Troster. São Paulo, Editora: Makron Books-1995. 
MILONE, Paulo Cesar \& LAGE, Beatriz Helena Gelas. Turismo Teoria e Prátic a. São Paulo, Editora: Atlas - 2000.

MOLO, Maria de Lourdes Rollemberg \& AMADO, Adriana Moreira. Noções de Macroeconomia. São Paulo, Editora: Manole - 2003.

NORDHAUS, William D. \& SAMUELSON, Paul A. Economia. São Paulo, 14 Edição. Editora: Mc Graw - Hill - 1982.

SANCHO, Amparo. Introdução ao Turismo. Tradução: Dolores Martin Rodrigues Comer. São Paulo, Editora: Roca - 2001.

STO NE, Gerald W. \& BYRNS, Ralph T. Macroeconomia. Tradução: Celina Martins Rama lho. São Paulo, Editora: Makron Books - 1995.

STUDART, Rogério; PAULA, Luiz Femando Rodrigues; SICSÚ, J oão; SOUZA, Francisco Eduardo Pires de; CARVALHO, Femando J. Cardim. Economia Monetária e Financeira. Rio de J a neiro, Editora: Campus - 2000.

\section{STIES:}

www.bacen.gov.br

www.econ.puc-rio.br 
www.ipeadata.gov.br

www.shopinvest.com.br/g lossa rio

www.turismo.gov.br/dadosefatos

www.unb.br/face/eco/inteco/dic iona riob.htm 
